\title{
Microrganismos do solo $\left({ }^{+}\right)$
}

\author{
FERDINANDO GALLI
}

Seção de Fitopatologia e Microbiologia

Escola Superior de Agricultura "Luiz de Queiroz"

(t) Aula inaugural de 1964. 


\section{GENERALIDADES}

Entre os constituintes do solo, um tem marcada influência sôbre as características dos demais: a fração biológica, constituida pelos diversos grupos de microrganismos que atuam sôbre a matéria orgânica do solo, no desenvolvimento contínuo de processos de síntese e de análise de compostos orgânicos, que fazem com que o solo seja considerado como uma entidade biológica $\epsilon$, portanto, com característicass dinâmicas, e não um substrato morto com caracteres físicos e químicos estáticos.

Os tipos de microrganismos são os mais diversos possíveis, e a quantidade é bastante elevada: evidentemente, a determinação do número exato dos constituintes da população microbiana de um determinado solo, em determinadas condições, é pràticamente impossível de ser feita, uma vez que encontra obstáculo irremovível nas técnicas até hoje empregadas para tal determinação: tais técnicas, quer aquelas em que se usa o microscópio, quer aquelas baseadas no desenvolvimento dos microrganismos em meio de cultura apropriado, por imperfeitas, por apresentarem um grande numero de limitações, nunca dão números siquer aproximados da quantidade de tais microrganismos. Dão o que se considera uma ideia mais ou menos vaga de tal população. Apesar dessas limitações impostas pelas técnicas de exame, sabe-se que a população microbiana é flutuante e, num mesmo local, varia bastante, na dependência do meio ambiente: temperatura, umidade, concentração de ions Hidrogênio, teor, tipo, composição e idade da matéria orgânica, além de outros fatôres.

\section{GRUPOS DE MICRORGANISMOS}

A palavra microrganismo é um termo um tanto quanto vago e é utilizada para indicar, de um modo geral, todos os sêres vivos de tamanho reduzido, invisíveis a olho nu; são assim, agrupados organismos tanto do reino animal como do vegetal. E pràticamente todos êles são encontrados no solo. Este constitui o habitat natural da imensa maioria dos microrganismos. Entre êles, merecem destaque, quer pelo número, quer pelas funções que desempenham, os que seguem.

As bactérias, constituem o grupo mais numeroso, quiçá o mais importante dentre os componentes microbianos do 
solo. Num solo normal, seu número aproximado, obtido por métodos comuns de análise, podem ser avaliados ao redor de vinte milhões de talos bacterianos por grama de solo. Essa quantidade corresponde a aproximadamente $0,01 \%$ do volume do solo na sua camada superior, ou, ainda, a cerca de trezentos quilogramas de talos bacterianos por hectare.

Evidentemente, tamanha massa de microrganismos deve exercer alguma ação sôbre as propriedades do solo: e exercem de fato. Entre as bactérias do solo, encontramos grupos que desempenham funções as mais variadas possíveis, e que as tornam o principal componente da população microbiana; são responsáveis por processos de síntese, bem como processos de análise, com acentuado reflexo sôbre a fertilidade do solo.

A quantidade de fung̨s, dentro da população microbiana do solo, é acentuadamente inferior a das bactérias; seu número, num solo nas condições do caso anterior, poderia variar entre quinhentos mil $\mathrm{e}$ dois milhões de indivíduos. Acontece, porém, que o talo dos fungos apresenta marcante diferença com relação ao talo bacteriano: o micélio daqueles tem diâmetro e comprimento muito maiores que os destas, de tal modo que, àquele número menor de indivíduos corresponde um volume de protoplasma, ou de célula viva, igual ou superior ao de bactérias. Conseqüentemente, o efeito exercido por essa massa de células, sôbre os demais constituintes do solo, é, quantitativamente, aproximadamente igual ao das primeiras. A ação dos fungos do solo é, porém, em diversos aspectos, diferente da ação desenvolvida pelas bactérias. Assim, o micélio filamentoso exerce efeito de ligação entre as partículas de solo, com acentuados reflexos nas propriedades físicas do mesmo. Os fungos não têm, de um modo geral, ação especial sôbre êste ou aquêle constituinte orgânico, nem têm função muito especializada; pelo contrário, sua ação é g̉eral sôbre os componentes da matéria orgânica, e se assemelha à ação dos microrganismos no seu conjunto. Os fungos têm desenvolvimento pouco mais lento que o das batérias e, portanto, não respondem tão prontamente a alterações do meio, principalmente adição de matéria orgânica, tão prontamente quanto aquelas. Sua ação, por isso mesmo, é mais prolongada e, de certo modo, constante. Por último, os fungos têm metabolismo diferente do das bactérias e, por êsse motivo, são capazes de atuar sôbre substratos os mais complexos, decompondo-os, como é, por exemplo, sua atuação sôbre a lignina. 
Os actinomicetos do solo, apesar de pertencerem ao mesmo grupo taxonômico das bactérias, exercem funções que, ressalvadas certas características próprias, se assemelham muito às desempenhadas pelos fungos.

Dois outros grupos merecem menção aqui: as algas, pouco numerosas, porém comuns.no solo, se diferenciam dos demais microrganismos pela sua característica de autotrofismo: sendo capazes de sintetizar as substâncias orgânicas de que necessitam, através do uso da energia solar, elas independem da matéria orgânica do solo e, por isso, e como conseqüência, não exercem nenhum papel de maior importância. Os protozoários, animais microscópicos, si bem que heterotróficos, parece não terem função maior que a de contribuir para um certo equilíbrio biológico, uma vez que é plenamente conhecida sua capacidade de se alimentarem de talos bacterianos.

\section{RELAÇÕES ENTRE MICRORGANISMOS E PLANTAS SUPERIORES}

Dado o méio em que se desenvolvem, os componentes da microtlora do solo, e as características dos seus processos metabolicos, êles mantëm com as plantas superiores, relaçöes as mais diversas; aqui, podem, sem maiores inconvenientes, ser agrupadas em tres tormas distintas.

A primeira delas compreende relaçöes de parasitismo. $O$ solo abriga certo numero de rungos e bactérias patogenicos as plantas; sao todos parasitas Iacultativos, capazes de se desenvolverem normaimence no solo; quando em presença da plania nospederra, agtrin como palogeno, aretanuo orgaus de

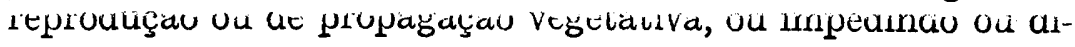
incullarruo o cesenvorvintenio hurmal da planua, produzinuo pourlaio das larzes, ou ainda proulzinoo uvenças sistemicas,

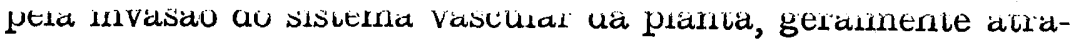
ves aas ralzes. rarasilas aesse upo apresentam com mequencia granae imporiancla econumicia e oleitcem gianats unclisiaues para un controle encience.

IVicrorganismos do solo e piancas superiores podem manter relaçöes de simbiose. U exempio mais comum e, talvez, o mais interessante, no presente caso, é constituído pela associação entre bactérias do gênero Rhizobium e plantas da 
família Leguminosae. Aquelas bactérias, desenvolvendo-se no interior de nódulos nas raízes dessas plantas, promovem a fixação do nitrogênio atmosférico, que é, posteriormente, utilizado pela planta. O mecanismo de tal fixação ainda hão está claramente elucidado. Entretanto, tem-se como válido que o nitrogênio elementar, sob a ação de enzimas produzidas pelas bactérias, é primeiro transformado num composto instável, a hidroxilamina. Esta se combina com um ácido orgânico, o ácido oxal-acético, sintetizado pela planta, dando origem ao ácido oximino-succinico, e, posteriormente, amino-ácidos, que são incorporados por ambos os simbiontes. Alguns pesquisadores, porém, aventam a hipótese de que a ação da bactéria é indireta: a planta seria o agente fixador, no caso apenas ativado por bio-catalizadores produzidos pela bactéria.

Outro exemplo de simbiose entre plantas e microrganismoś seria o das micorrizas. São associações entre fungos do solo e raízes de plantas superiores, das quais resultam órgãos às vêzes com características estruturais próprias; distingue-se dois tipos diferentes de micorrizas: ectotróficas, nas quais o fungo simbionte forma u'a manta de micélio envolvendo a raiz da planta e apresenta hifas que penetram espaços intercelulares dos tecidos corticais da raiz; nas endotróficas, o micélio do fungo se desenvolve quasi que exclusivamente nos tecidos da raiz, e apenas algumas hifas se extendem para o exterior, penetrando entre as partículas de solo. Em ambos os casos, o micélio do fungo substitui os pêlos absorventes da raiz, não encontrados nessa região.

Tem-se como certo que as relações entre ambos os simbiontes se desenvolvem à base de troca: a planta supre o fungo com os hidratos de carbono, amino-ácidos e outros compostos orgânicos necessários ao seu metabolismo; êste, por sua vez, por intermédio das hifas em contacto com o solo, supre a planta de elementos minerais necessários ao desenvolvimento desta última. Muitas vêzes a presença de micorrizas é essencial para o desenvolvimento normal da planta, principalmente em casos em que o solo é deficiente em elementos minerais como o fósforo e o nitrogênio. Em outros casos, si bem que não essencial, a micorriza é benéfica: plantas com micorrizas têm melhor desenvolvimento.

Esse tipo de associação é de enorme importância nos problemas relacionados com reflorestamento, principalmente quando êste é feito com plantas exóticas, que, naturalmente, 
não podem não encontrar no nôvo ambiente os mesmos componentes da microflora do seu habitat de origem.

O terceiro tipo de relação microrganismos do solo plantas superiores resulta do característico de "heterotrofismo" comum à grande maioria dos microrganismos que têm o solo como habitat natural.

Incapazes de se utilizarem do carbono mineral como fonte das suas necessidades em substância orgânica, incapazes de se mostrarem patogênicos às plantas; incapazes ainda se virem em simbiose com elas, utilizam-se da matéria orgânica prèviamente sintetizada através da função clorofiliana, incorporada primeiro à própria planta, depois ao corpo dos animais que dela fizeram uso como alimento, e, por último, levada ao solo na condição de restos animais ou vegetais, ou ainda, excretada no solo pelo sistema radicular.

Considerando-se de um lado o grande número de microrganismos existentes, cada um dêles produzindo um sistema enzimático próprio, característico, e de outro, a grande diversidade de compostos constituintes da matéria orgânica incorporada ao solo, pode-se ter idéia apenas aproximada do grande número de processos de síntese e de análise que se desenvolvem no solo: síntese para produção dos constituintes celulares do talo microbiana, análise para obtenção de energia. Resultantes finais dêsse processo complexo, são o retorno do carbono à atmosfera, sob a forma mineral disponivel às plantas superiores, e a liberação, no solo, dos elementos minerais em formas passíveis de serem utilizadas pelas plantas, contribuindo, portanto, para a circulação contínua dos diversos elementos na natureza.

\section{BIBLIOGRAFIA}

ALEXANDER, M., 1961. Introduction to soil mocrobiology. John Wiley \& Sons, Inc. N. York, 472 p.

BURGES, A., 1958. Microrrganisms in the soil. Hutchinson Univ. Library. Londres. $188 \mathrm{p}$.

HENDLIN, D., 1954. The nutrition of microorganism. Ann. Rev. of Microbiology, 8: 47-70.

KRASILNIKOV, M. A., 1961. Soil microorganisms and higher plants. The Israel Program for Scientific Translaction, Jerusalem, 474 p.

LOCHHEAD, A. G., 1952. Soil Microbiology. Ann. Rev. of Microbiology, 6: 185-206.

WAKSMAN, S. A., 1952. Soil Microbiology. John Wiley \& Sons, Inc. N. York, $356 \mathrm{p}$. 